\title{
THE EFFECT OF COOPERATIVE LEARNING MODEL OF THINK PAIR SHARE BASED ON CONCEPT MAPPING TOWARDS CIVICS ACHIEVEMENT
}

\author{
Suyatni, N.W..$^{*}$, Rendra, N.T. ${ }^{2}$, Rati, N.W. ${ }^{3}$
}

1,2,3Universitas Pendidikan Ganesha, Singaraja, Indonesia

\begin{tabular}{l} 
A R T I C L E I N F 0 \\
\hline Article history: \\
Received 19 March 2018 \\
Received in revised form \\
6 April \\
Accepted 12 May 2018 \\
Available online 25 June \\
2018 \\
\hline Keywords: \\
Civic Achievement, \\
Concept Mapping, \\
Think Pair Share
\end{tabular}

\begin{abstract}
A B S T R A C T
This study is aimed at investigating the difference of students' civics achievement between those who are taught by Think Pair Share model based on concept mapping and those who are taught by conventional learning model of the fifth grade students in Elementary School of Cluster I in Petang District. It is a quasiexperimental research using non-equivalent post-test only control group design. The population of this research is 102 students in grade V in Elementary School of Cluster I Petang District. The samples of this research are fifth grade students of SD Negeri 3 Carangsari as experimental group and fifth grade students of SD Negeri 1 Carangsari as control group. The data of civics achievement were collected by using multiple choice tests. The data obtained were analyzed using descriptive statistics and inferential statistical analysis ( $t$-test). The result showed that $t_{\text {count }}=3,83$ and $t_{\text {table }}=2,03$ ( $t_{\text {count }}>t_{\text {table }}$ ) which can be concluded that there are significant difference between the students' civics achievement between those who were taught by Think Pair Share learning model based on concept mapping and those who were taught by the conventional learning model in grade V in Elementary School of Cluster I Petang District of Badung Regency in academic year 2017/2018.
\end{abstract}

\section{Introduction}

Education is a conscious effort to improve qualified human resources. Nowadays, qualified human resources should be realized to face the global competition. According to the laws nomor 20 year 2003, it is said that education is a conscious and planned effort to create learning and teaching situation where the students can actively develop their potential capacity for the spiritual religion, self-control, character, intelligence, moral, and skills required by themselves, society, and nation.

Education is an important means in developing various self-potencies to create qualified human resources. In a broaden definition, education has general purpose which is emphasized in the laws nomor 20 year 2003, Chapter II Article III, that national education has a function of developing skills and build characters as well as grade national civilization in ridding the nation development, developing students' potency to be faithful humans to the God with moral, knowledge, proficiency, creative, independence, and responsibility. Based on this explanation, it is concluded that education is aimed at guiding human into adulthood which means guiding the students to be capable of being independent by themselves in the society. It makes education be the center of attention by educators, society, and government. It is believed that it can give positive impacts for every one.

To reach the goal, several subjects as it is required in Article 37 Subsection 1 about National Education System are suggested. One of them is civics. Civics is one of the subjects containing knowledge of concept, value, moral, and norm. The real implementation of civics will contribute to the students' ability in comprehending the concept, value, moral, and norm in society. According to Wardhiana (2013), civics is a subject which focuses on the forming of humans who can comprehend and implement their rights and duties to be intelligent, skilled, and characterized Indonesian citizen as it is required in Pancasila and UUD 1945. The purpose of civics is to shape good citizen. Good citizen is people who can act accordingly based on the rules; therefore, civics has an important role in daily life. The higher the quality 
of civics education in elementary school, the better the output will be. The output here is people who has been through the process of education, that, improving the uqlity of civics education is a must.

The improvement of the quality of education is a part of the role of teachers. Teachers as the educators are demanded to develop the innovative and interesting learning based on the curriculum and students' situation. Such learning will help create the condusive learning situation. Tecahers also need to know students' background and environment, so that they can be involved in learning (Rahayu, 2010). With the involvement of students in learning, it is hoped that they can acquire meaningfull knowledge/concept.

Based on the result of the interview, observation, and document noting in Elementary School of Cluster I in Petang District, it was obtained information of several problems occured in civics. The result of interview with several teachers who taught civics in elementary school of Cluster I in Petang District on 11th December 2017, several obstacles encountered by teachers in teaching civics were 1) time allotment that was not enough to deliver the material, 2) students' pasiveness during the class, and 3) students' low confidence in asking or giving their opinion of the problems related to the materials during the class.

The observation was done from $12^{\text {th }}$ to $13^{\text {th }}$ December 2017 during the learning process in the class. The result showed on several problems occurred. First, teachers delivered the materials conventionally by using lecturing method during the class. Then, students were asked to take note on those delivered mamterials in their notebook. After that, teachers asked them to do the assignments in their books. It pointed that the students learnt by receiving and memorizing the information delivered by their teachers (teacher-center). Second, the learning eas not interesting because the teachers did not use any media during the class, so the students were passive and bored. By using media, the learning would have been interesting for the students and the material would have been easily comprehended. Third, the students did not comprehend the material maximally because of the implementation of teacher-center method, so it gave impact on their low achievement.

Based on the document noting, it was known that the average of students' cognitive achievement in grade V of Cluster I in Petang District was in the interval of 72.3 - 75.6. If it was conversed into PAP scale (Agung, 2014:251), the interval was categorized as sufficient. It means that the average score of students' civics achievement was low.

The students' low achievement is a serious problem to solve. Think pair Share is a model that can be used to solve the problem because this ccoperative model gives more opportunity for the students to think, respond, and help each other. Arend said that think-pair-share model is an effective way to create various discussion situations in the class (cited in Asmani, 2016:123). The students are required to actively discuss the problem with their friends and work together in solving the problem related to the material being discussed.

This is in line with Kurniasih's opinion (2015:58) that "through think-pair-share model, the students are accostumed to express their opinion and respect others related to the material or the learning goal". The goal of this ccoperative model is to improve the academic acquisition, improve social skills, and help them think critically as well as to improve their understanding in comprehending the concepts (Rusman, 2012).

The cooperative model think-pair-share will be more effective if it is combined with learning media in delivering the material. One of the media that can be used is concept mapping because it can be seen directly by the students. It enables the students in understanding the material for it contains the materials which are related to each others and the understanding of the concepts is the key. This is in line with Jailani (2016) who states that concept mapping emphasizes on the proportional relationship among the concepts, so that it helps students easily understand them. Therefore, using this model combined with concept mapping, classroom situation that can motivate students to learn can be created, so that the achievement can improve.

Based on the explanation above, it is important to do this research, entitle "The effect of cooperative learning model of think-pair-share combined with concept mapping towards fifth grade students' civics achievement in Cluster I in Petang district of badung Regency in academic year of $2017 / 2018$ ". This study is aimed at investigating the influence of the cooperative learning model of thinkpair-share combined with concept mapping towards fifth grade students' civics achievement in Cluster I in Petang district of badung Regency in academic year of 2017/2018.

\section{Methods}

This study was conducted in Elementary School of Cluster I in petang District. This is quasi experimental study which used Non Equivalent Posttest Only Control Group Desain. The design is presented in table 1. 
Table 1. Non Equivalent Posttest Only Control Group Desain

\begin{tabular}{ccc}
\hline Group & Treatment & Post-test \\
\hline Experiment & $\mathrm{X} 1$ & 01 \\
Control & - & 02 \\
\hline
\end{tabular}

The population is 102 fifth grade students of Cluster I in Petang District of Badung Regency (7 classes). To know the equivalence of population's civics achievement, ANAVA test for cognitive domain in semester I was conducted.

Based on the result of ANAVA A in 5\% significance, it was obtained that $\mathrm{F}_{\text {hitung }}$ was 1.68 , whereas $F_{\text {tabel }}$ in $d_{b} b_{\text {antar }}=6$ and $d b_{\text {dalam }}=97$ was 2.19 . It means that $F_{\text {hitung }}$ was lower than $F_{\text {tabel }}(1.68<2.19)$, thus, $H_{0}$ was accepted and $\mathrm{H}_{1}$ was rejected. It indicates that fifth grade students' civics achievement in Cluster I in Petang District in academic year of 2017/2018 was equivalent. Sample was done by using random sampling. SD Negeri 3 Carangsari was chosen as experimental group and SD Negeri 1 Carangsari was chosen as control group. The experimental group was taught by using cooperative learning model of think-pair-share combined with concept mapping and control group was taught conventionally.

The coefisien of content validity of students' civics achievement in cognitive domain was 1.00. If the coefisien was conversed into content validity criteria, the coefisien was in the range of $0.800-1.00$ and considered as high.

The validity test of the items was done by using Microsoft Office Excel 2007 for Windows program. Among 40 items that were tried out, 36 items were valid and 4 items were not. The reliability test of items was done by sing Microsoft Office Excel 2007 for Windows program. Based on the result, it was obtained that the coefisien was 0.86 which means that the test has very high reliability. The item difficulty item, based on the result that showed $\mathrm{Pp}=0.59$, was considered as medium. The result of item discrimination based on the analysis using Microsoft Office Excel 2007 for Windows program showed $D_{p}=$ 1.42 which means that the items were good. According to the test, 2 items were very good, 18 items were good, 11 items were sufficient, and 5 items were less sufficient.

There were two variables used, namely dependent variable and independent variable. The independent variable in this study were cooperative learning model of think-pair-share combined with concept mapping for experimental group and conventional technique for control group, while the dependent variable was civics achievement. The data were collected through test. The instrument used was objective multiple-choice test which was tried out firstly in the class to check its validit, reliability, item difficulty, and item discrimination. The data were then given to the experimental group and control group as the post-test. The data were analysed statistically and descriptively to know the mean, median, mode, standard of deviation, variance, maximum score, and minimum score. The data, in this study, was presented in poligon curve. The hypothesis was tested by using t-test (separated variances). Some prerequisite tests were done for the further analysis such as normality test and homogenity test to know whether the data were distributedly normal and homogent.

\section{Findings and Discussion}

The data of this study were civics achievement of students who were taught by using cooperative learning model of think-pair-share combined with concept mapping for experimental group and students taught conventionally. The analysis showed differences of experimental group and control group. Mean, median, mode, variance, standard of deviation, maximum score, and minimum score showed difference of students' achievement in SD Negeri 3 Carangsari and SD Negeri 1 Carangsari. The description of students' achievement can be seen in table 2 .

Table 2. Civics Achievement Description

\begin{tabular}{ccc}
\hline Statistics Data & \multicolumn{2}{c}{ Civics Achievement } \\
\cline { 2 - 3 } Mean & Experimental Group & 17,71 \\
Median & 20,49 & 15,25 \\
Mode & 21,25 & 14,70 \\
Variance & 21,70 & 15,17 \\
Standard of Deviation & 16,45 & 3,89 \\
Minimum score & 4,06 & 9 \\
Maximum score & 13 & 25 \\
\hline
\end{tabular}


Based on the table above, experimental group where students were taught by using think-pairshare model obtained mean $(\mathrm{M})=20.94$, median $(\mathrm{Md})=21.25$, mode $(\mathrm{Mo})=21.70$, variance $\left(\mathrm{s}^{2}\right)=16.45$, standard of deviation $(s)=4.06$, the lowest score of 13 , and the highest score of 29 . Mean, median, mode were presented in polygon curve to easily see and understand the relationship among them. The relationship among mean, meian, and mode can be used to determine the declivity of frequency distribution. The experimental group's achievement can be seen in figure 1.

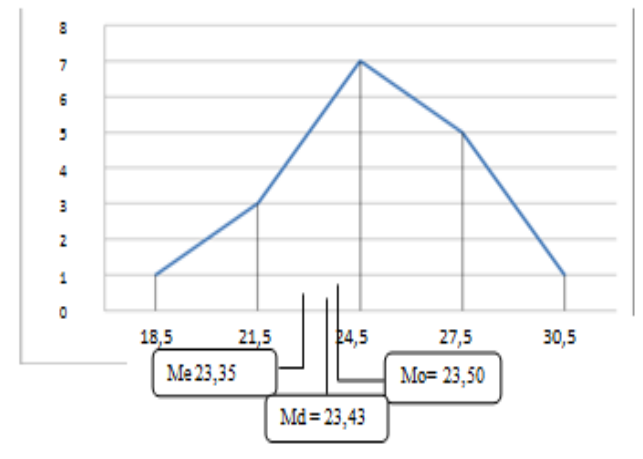

Figure 1 Experimental Group's Achievement

Based on the polygon graph above, it is seen that in the experimental group, the mode is higher than median and meian is higher than mean (Mo $>\mathrm{Md}>\mathrm{M}$ ), so the curve is a kind of negative cross curve which indicates high score. If it is conversed into category decree guidance, the experimental group's civics achievement is high.

Meanwhile, in the control group, the mean (M) was around 17.71, median (Md) was about 15.25, mode (Mo) was 14.70 , variance $\left(\mathrm{s}^{2}\right)$ was 15.17 , standard of deviation (sd) was 3.89 , minimal score was 9 , and maximal score was 25. The data of control group's achievement is presented in figure 2 .

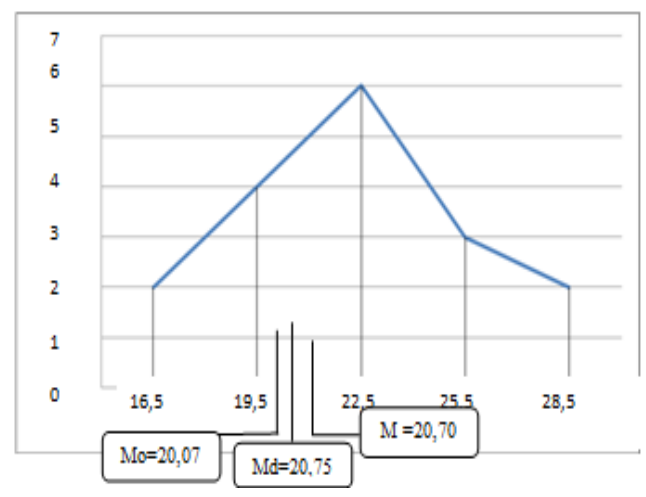

Figure 2. Control Group's Achievement

The polygon graph above showed that the mode was lower than median and median was lower than mean (Mo $<\mathrm{Md}<\mathrm{M}$ ), so the curve is a kind of positive cross curve which points at low achievement score. If it was conversed into category decree guidance, control grou's civics achievement was sufficient. It indicated that cooperative learning model of think-pair-share class has higher average score than conventional class.

Prerequisite test was done before testing the hypothesis. The prerequisite test involved normality testing and variance homogeneity testing. Normality testing was done to know whether the data of experimental group and control group was normal. Based on the result using chi-kuadrat formula, it was obtained that the post test of $\chi^{2}$ hitung of experimental group was 0.515 and $\chi^{2}$ tabel with significance level of $5 \%$ and $\mathrm{db}$ of 2 was 6.251. It indicated that $\chi^{2}$ hitung of experimental group's post test was lower than $\chi^{2}$ tabel ( $\chi^{2}$ hitung $<\chi^{2}$ tabel), so the data of experimental group's post test were normal. Meanwhile, $\chi^{2}$ hitung of control group's post test was 1.081 and $\chi^{2}$ tabel with significance level 
of $5 \%$ and db of 2 was 6.251. It indicated that $\chi^{2}$ hitung of control group's post test was lower than $\chi^{2}$ tabel ( $\chi^{2}$ hitung $<\chi^{2}$ tabel), so the data of control group's post test were normal.

After normality testing was done, homogeneity testing was conducted. Homogeneity testing was done to know whether the data were homogent. It was done by dividing the highest variance and the lowest variance using F-test with the criteria of $\mathrm{F}_{\text {hit }}<\mathrm{F}_{\mathrm{tab}}$. Based on the analysis, $\mathrm{F}_{\text {hit }}$ of both groups' post test was 1.08 , while $F_{\text {tab }}$ with $d_{b} b_{\text {pembilang }}=16$, db $b_{\text {penyebut }}=16$, and significance level of $5 \%$ was 2,33 . It indicated that the data variance of both groups was homogent.

After analyzing the data descriptively and based on prerequisite testing, the hypothesis was tested. The hypothesis is whether there is the effect of cooperative learning model of think-pair-share combined with concept mapping towards fifth grade students' civics achievement in Elementary School of Cluster I in Petang District of Badung Regency in academic year of 2017/2018.

The hypothesis testing was done by using t-test of independent sample (non correlation) with the formula of separated varians in which $\mathrm{HO}$ would be rejected if thit $>\mathrm{ttab}$ and $\mathrm{H} 0$ was accepted if thit < ttab. ttab was obtained from $t$ - table distribution in significance level of $5 \%$ with $d b=n 1+n 2-2$. The recapitulation of t-test between experimental group and control group is presented in table 3 .

Table 3. Recapitulation of t-tes

\begin{tabular}{cccccc}
\hline Group & $\mathbf{N}$ & $\mathbf{X}$ & $\mathbf{s}^{2}$ & $\mathbf{t}_{\text {hit }}$ & $\mathbf{t}_{\text {tabel }}(\mathbf{t . s} \mathbf{5 \%})$ \\
\hline Experiment & 17 & 20,94 & 16,45 & \multirow{2}{*}{3,83} & 2,03 \\
Control & 17 & 15,71 & 15,17 & & \\
\hline
\end{tabular}

The table above showed that $t_{\text {hit }}$ was 3.83 and $t_{\text {tab }}$ was 2.03 with $\mathrm{db}=32$ in significance level of $5 \%$. Based on the testing criteria, because $t_{h i t}>t_{t a b}$, then $H_{0}$ was rejected and $h_{1}$ was accepted. It indicated that there was significant difference of civics achievement between students who were taught by cooperative learning model of think-pair-share combined with concept mapping and those who were taught conventionally of the fifth grade students in Cluster I in Petang District, Badung Regencyin academic year of $2017 / 2018$.

The discussion of this research and hypothesis testing involves the descriptive analysis and statistical analysis including independent variable and dependent variable. The independent variable in this study is Think-Pair-Share and the dependent variable is civics achievement. The discussion of the hypothesis testing analysis is presented below.

Better achievement can be reached if the students can maximally understand the material through several ways. Not only that, the teachers are also demanded to be more creative in packing the learning process. Based on the result of t-test, it was kobtained that thitung $=3,83$ and ttabel $(\mathrm{db}=$ and significance level of $5 \%)=2,03$ which indicated that the result of the hypothesis testing was significant. It meant that there was significant difference of civics achievement between students who were taught by cooperative learning model of think-pair-share combined with concept mapping and those who were taught conventionally.

This significant difference shows that the implementation of cooperative learning model of thinkpair-share influences students' civics achievement. How this ccoperative model and conventional teaching model influence the achievement can be seen from the average score of civics achievement. The average of experimental group's civics achievement was 23.35, while control group's civics achievement was 20.70. It indicated that the experimental group's mean score was higher than control group's (Meksperimen > Mkontrol).

The significant difference of students' achievement between students who were taught by cooperative learning model of think-pair-share and those who were taught conventionally was cause by several factors.

First, the different treatment on the learning steps and process. In think step, the students actively think of the answer of the problems given by the teachers based on students' understanding of the material. They also comprehend the material being learnt. In pair step, the students share their thought with their partners and find the best answer of the problem. This partnership improves students' braveness to state their opinions so they can interact and communicate in solving the problem well. This is in line with Kurniasih (2015) who states that it is a kind of learning prepared that influences students' interaction. Good interaction enables students in solving the problems to get the best result so they will actively respond the problems related to the material based on the discussion to reach the learning goal. In share step, the students share their discussion to the other groups to broaden their understanding towards the material. These three steps create different learning situation. Interesting learning situation 
influences students' understanding towards the material in improving their achievement. This is in line with Sunita (2014) who states that think-pair-share activity can give interesting learning activity that affects students' understanding well.

Second, think-pair-share model combined with concept mapping affects on students' knowledge of civics concept understanding. the knowledge can be acquired in a simple way that gives influence on the improvement of students' ability during the learning process. It is supported by Dahar (cited in Trianto, 2014) that students can see the concepts of certain subjects through concept mapping so they can have good and meaningful understanding. The use of concept mapping in think-pair-share activity was conducted in the pre-activity when the teacher delivered the material to enabled students tounderstand the material easily. This media gives opportunity for the students to master the material independently through teacher's feedback.

Third, cooperative learning model of think-pair-share combined with concept mapping is really good to apply in civics because it involves many schema knowledge showing the proportional relationship among the concepts. This model enables students to easily acquire the knowledge (Jailani, 2016). It also influences on students' achievement.

The different process of the implementation between experimental group and control group affects different result on students' civics achievement. The learning activity with think-pair-share model combined with concept mapping gives better understanding ability than the learning activity in conventional way.

The result of this study was supported by several research. First, Wibawa (2016) stated that there was significant difference on students' achievement after the implementation of think-pair-share model. His study showed that students' achievement taught by the cooperative model was better. Second, research by Juliantari (2017) showed that the same thing, that, students' achievement in both classes was significantly different, that experimental class was better than conventional class. Therefore, the cooperative model of think-pair-share with concept mapping positively influences more on students civics achievement of fifth grade students in SD Negeri 3 Canangsari, while conventional activity in control group does not show significant influence.

Based on the discussion above, it can be concluded that cooperative learning model of think-pairshare with concept mapping positively influences on students' civics achievement. It indicates that significant difference was found through the use of coopretaive learning model of think-pair-share with concept mapping towards fifth grade students' civics achievement in Cluster I, Petang District, Badung Regency in academic year of 2017/2018.

\section{Conclusion}

According to the result of hypothesis testing and the discussion, it is concluded that there is significant different of students' civics achievement between the group with ccoperative model of thinkpair-share with concept mapping and the group with conventional model. Through the use of think-pairshare model with concept mapping, it gives positive influences towards fifth grade students' civics achievement in Cluster I, Petang District, Badung Regency in academic year of 2017/2018.

The result can be seen from the mean score of the groups, that the experimental group's mean score was 23.35 and control group's mean score was 20.83. It indicated that experimental group's mena score was higher than control group's. The different of this mean score was the proof that cooperative model of think-pair-share gives positive effects on students' achievement.

Based on the result of this study, it is suggested that (1) students need to work together and be more active during the learning process as well as improve their understanding independently through many learning experiences, (2) the teachers should innovate themselves in managing the class by implementing innovative learning strategy supported by relevant learning media that can be packed in a simple concept to improve students' comprehension, (3) the headmaster should use this study as reference in making the school policy and ask the teachers to choose and decide the innovative learning model, (4) the other researches should use this study as reference to do further researches in the same field

\section{References}

Agung, A.A.G. (2014). Metodologi Penelitian Pendidikan. Singaraja: Aditya Media Publishing.

Asmani, J.M. (2016). Tips Efektif Kooperatif Learning. Yogyakarta: Diva Press. 
Jailani. (2016). Penggunaan Peta Konsep untuk Belajar Bermakna dan Peningkatan Pemahaman Siswa dalam Pembelajaran Biologi. Jurnal Serambi PTK, 3(2).

Kurniasih, I. \& Sani, B. (2015). Ragam Pengembangan Model Pembelajaran Untuk Meningkatkan Profesionalitas Guru. Jakarta: Kata Pena.

Rahayu, E.S. \& Nuryata, I.M. (2010). Pembelajaran Masa Kini. Jakarta: Sukarmita Training and Publishing.

Rusman. (2015). Pembelajaran Tematik Terpadu Teori Praktik Dan Penilaian. Jakarta: PT. Raja Grafindo Persada.

Shoimin, A. (2014). 68 Model Pembelajaran Kooperatif Dalam Kurikulum 2013. Yogyakarta: Ar-Ruzz Media.

Sunita, M.D. (2014). "TPS (Think-Pair-Share): An Active Learning Strategy to Teach Theory of Computation Course" International Journal of Educational Research and Technology (IJERT), 5 (4), 62-67.

Undang-undang Republik Indonesia No. 20 Tahun 2003 Tentang Sistem Pendidikan Nasional. 2003. Jakarta.

Wardhiana, I.K.S. (2013). Penerapan Model Pembelajaran Kooperatif Tipe Snowball Throwing untuk Meningkatkan Keaktifan dan Hasil Belajar PKn Kelas V SD Negeri 1 Bungbungan. Jurnal Mimbar PGSD Universitas Pendidikan Ganesha, 1(1).

Wibawa, N.R.A. (2016). Pengaruh Model Pembelajaran Kooperatif Tipe Think Pair Share (TPS) Berbantuan Compatc Disc (CD) Interaktif Terhadap Hasil Belajar IPA Sisw Kelas IV SD Gugus IV Kecamatan Tejakula Kabupaten Buleleng Tahun Pelajaran 2015/2016. Jurnal Mimbar PGSD Universitas Pendidikan Ganesha, $4(1)$. 